\title{
Glacier dynamics at Helheim and Kangerdlugssuaq glaciers, southeast Greenland, since the Little Ice Age
}

\author{
S. A. Khan ${ }^{1}$, K. K. Kjeldsen ${ }^{2}$, K. H. Kjær ${ }^{2}$, S. Bevan ${ }^{3}$, A. Luckman ${ }^{3}$, A. Aschwanden ${ }^{4}$, A. A. Bjørk ${ }^{2}$, N. J. Korsgaard ${ }^{2}$, \\ J. E. Box ${ }^{5}$, M. van den Broeke ${ }^{6}$, T. M. van Dam ${ }^{7}$, and A. Fitzner ${ }^{8}$ \\ ${ }^{1}$ DTU Space - National Space Institute, Technical University of Denmark, Department of Geodesy, Kgs. Lyngby, Denmark \\ ${ }^{2}$ Centre for GeoGenetics, Natural History Museum, University of Copenhagen, Copenhagen, Denmark \\ ${ }^{3}$ Department of Geography, College of Science, Swansea University, Swansea, UK \\ ${ }^{4}$ Geophysical Institute, University of Alaska, Fairbanks, USA \\ ${ }^{5}$ Geological Survey of Denmark and Greenland, Copenhagen, Denmark \\ ${ }^{6}$ Institute for Marine and Atmospheric Research, Utrecht University, Utrecht, the Netherlands \\ ${ }^{7}$ Faculté des Sciences, de la Technologie et de la Communication, University of Luxembourg, Luxembourg \\ ${ }^{8}$ Centre for Ice and Climate, University of Copenhagen, Copenhagen, Denmark
}

Correspondence to: S. A. Khan (abbas@space.dtu.dk)

Received: 23 January 2014 - Published in The Cryosphere Discuss.: 21 February 2014

Revised: 28 June 2014 - Accepted: 13 July 2014 - Published: 18 August 2014

\begin{abstract}
Observations over the past decade show significant ice loss associated with the speed-up of glaciers in southeast Greenland from 2003, followed by a deceleration from 2006. These short-term, episodic, dynamic perturbations have a major impact on the mass balance on the decadal scale. To improve the projection of future sea level rise, a long-term data record that reveals the mass balance beyond such episodic events is required. Here, we extend the observational record of marginal thinning of Helheim and Kangerdlugssuaq glaciers from 10 to more than 80 years. We show that, although the frontal portion of Helheim Glacier thinned by more than $100 \mathrm{~m}$ between 2003 and 2006, it thickened by more than $50 \mathrm{~m}$ during the previous two decades. In contrast, Kangerdlugssuaq Glacier underwent minor thinning of 40-50 m from 1981 to 1998 and major thinning of more than $100 \mathrm{~m}$ after 2003. Extending the record back to the end of the Little Ice Age (prior to 1930) shows no thinning of Helheim Glacier from its maximum extent during the Little Ice Age to 1981, while Kangerdlugssuaq Glacier underwent substantial thinning of 230 to $265 \mathrm{~m}$. Comparison of sub-surface water temperature anomalies and variations in air temperature to records of thickness and velocity change suggest that both glaciers are highly sensitive to short-term atmospheric and ocean forcing, and respond very quickly to small fluctuations. On century timescales, however, multiple
\end{abstract}

external parameters (e.g. outlet glacier shape) may dominate the mass change. These findings suggest that special care must be taken in the projection of future dynamic ice loss.

\section{Introduction}

During 2003-2006, almost 50\% of the total ice loss of the Greenland Ice Sheet (GrIS) occurred in southeast Greenland (Chen et al., 2011; Khan et al., 2010; Luthcke et al., 2006; Rignot et al., 2008; Stearns and Hamilton, 2007; Velicogna and Wahr, 2006; Van den Broeke et al., 2009). Two of the largest outlet glaciers in this region, Helheim and Kangerdlugssuaq glaciers, with a total catchment-wide drainage area of about $250 \times 10^{3} \mathrm{~km}^{2}$ (Fig. 1a), contributed up to $50 \mathrm{~km}^{3} \mathrm{yr}^{-1}$ of ice loss (Luckman et al., 2006; Stearns and Hamilton, 2007; Khan et al., 2007), which is itself more than half of the southeast Greenland total (Joughin et al., 2010; Luthcke et al., 2006; Velicogna and Wahr, 2006), indicating the particular importance of these two major outlet glaciers.

The mass loss of the GrIS has accelerated due to a combination of increased ice velocity (Howat et al., 2007; Joughin et al., 2010; Khan et al., 2014; Luckman et al., 2006; Pritchard et al., 2009; Rignot et al., 2008), causing dynamic 

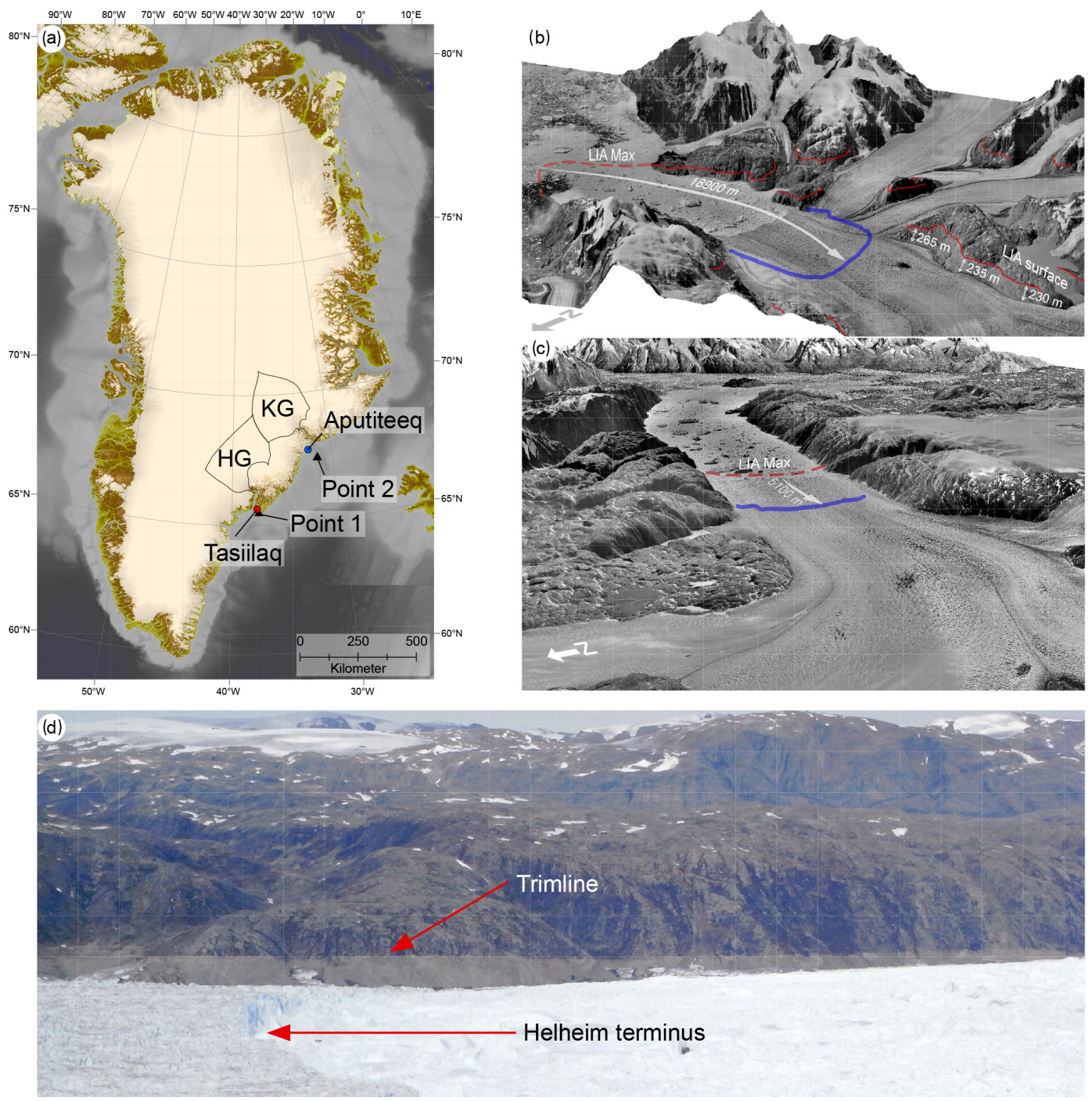

Figure 1. (a) Map of south Greenland and the location of Helheim Glacier (HG) and Kangerdlugssuaq Glacier (KG). The solid black lines denote the catchments of Helheim and Kangerdlugssuaq glaciers. The locations of meteorological stations at Tasiilaq and Aputiteeq operated by the Danish Meteorological Institute (DMI) are shown by red and blue circles, respectively. Black triangles represent points where we created the SST anomaly time series. (b) Orthophoto from 1981 of Kangerdlugssuaq Glacier draped onto the 1981 Digital Elevation Model (DEM). Red lines show the extent during the Little Ice Age (LIA) maximum and the blue lines shows the glacier front position in 2012. (c) Same as (b) but for Helheim Glacier. Note that due to glacier fluctuations during the 20th century Helheim Glacier was very close to its LIA maximum extent by 1981. (d) Photo of the Helheim terminus in August 2006.

ice loss, and a warmer atmosphere (Van den Broeke et al., 2009), leading to enhanced surface meltwater runoff. Recent model results use data from the last decade as initial conditions to model the GrIS's contribution to sea level rise by 2100 (Nick et al., 2013; Price et al., 2011). The last decade, however, is not necessarily typical of conditions at these glaciers and appears to have been dominated by anomalous dynamic behaviour (Bevan et al., 2012). Improved projections of ice sheet contributions to global sea level change require longer-term data records that reveal the mass balance beyond the last decade, and a better understanding of the sensitivity of dynamic thinning to climate forcing on decadal time scales. Here we extend the observational record of marginal thinning to more than 80 years for the two most prominent outlet glaciers in southeast Greenland, Helheim and Kangerdlugssuaq glaciers. We analyse marginal changes from before 1930 and 2012, and test their sensitivity to subsurface water temperature (SSWT) anomalies and variations in air temperature. 


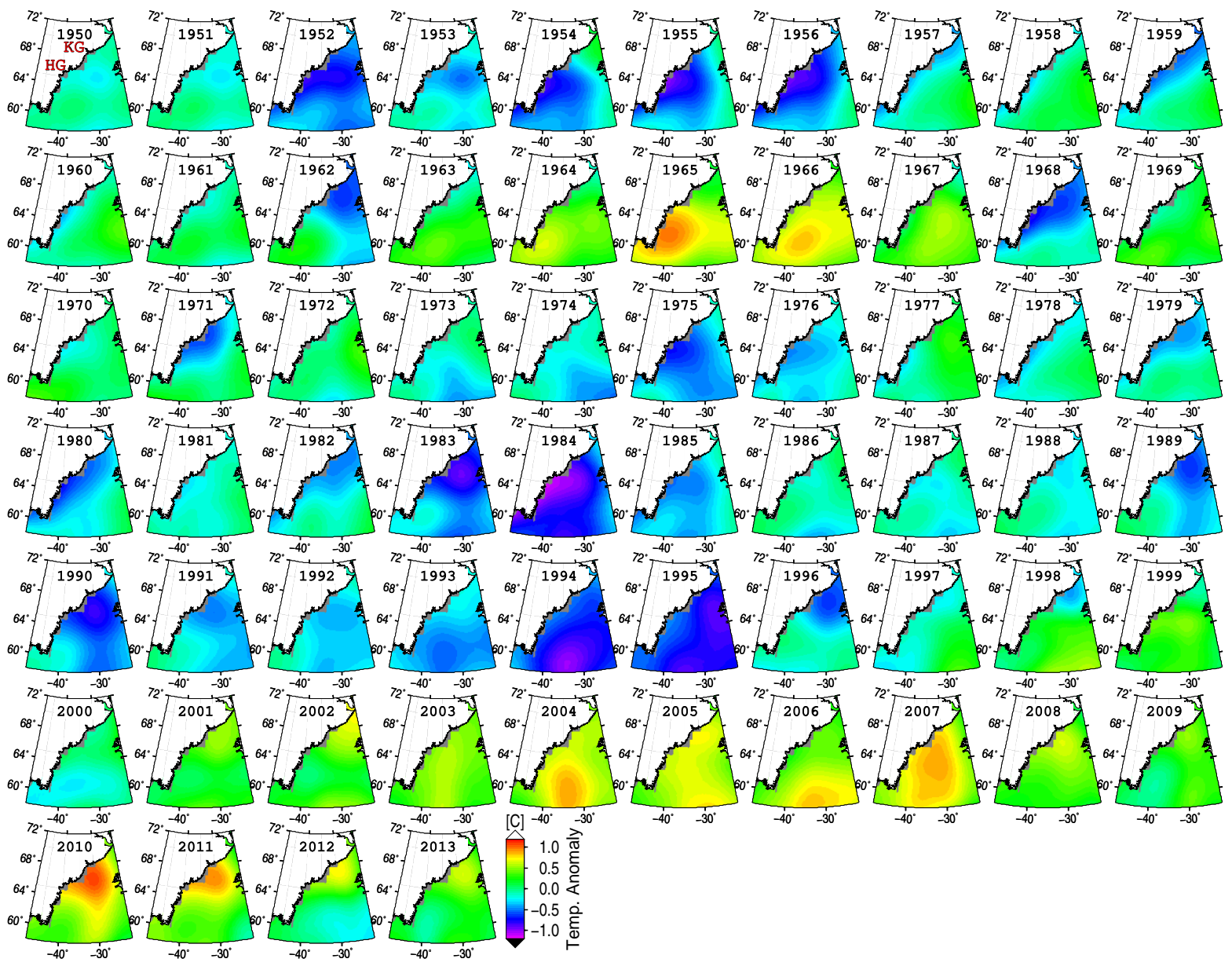

Figure 2. Mean annual sub-surface water temperature anomalies at a depth of $315 \mathrm{~m}$.

\section{Data}

\subsection{Surface elevation}

To map changes in Helheim and Kangerdlugssuaq glaciers, we use altimeter surveys from NASA's Airborne Topographic Mapper (ATM) flights during 1993-2011 (Krabill, 2012), supplemented with high-resolution Ice, Cloud and land Elevation Satellite (ICESat) laser altimeter data (Zwally et al., 2012) from 2003 to 2009. To assess thinning prior to 1993 , we analyse aerial photos from 1981 covering the frontal portion of Helheim and Kangerdlugssuaq glaciers. Aerial photographs on a scale of $1: 150000$ of Helheim and Kangerdlugssuaq glaciers were taken between 30 July and 14 August 1981 by the Danish Geodata Agency in order to provide stereoscopic coverage of ice-free terrain including nunataks. Images and ground control points were provided by the Danish Geodata Agency. The latter was comprised of 233 points of known height derived from aero-analytical triangulation using geodetically surveyed stations. These were provided in the Greenland 1996 reference system (GR96) and transformed to ellipsoid heights for our purposes. The digital mapping software SOCET SET 5.5 (BAE Systems) and ArcGIS 10 (Esri) were used to process the data. We used these data to derive a $25 \times 25 \mathrm{~m}$ gridded Digital Elevation Model (DEM) for 1981 in the Universal Transverse Mercator (UTM) coordinate system (zone 24) with elevations referenced to the height above the ellipsoid (World Geodetic System 1984). We generated the DEMs for the two regions from 27 photos.

\subsection{Ice flow speeds}

Surface flow speeds (Bevan et al., 2012) were measured by applying feature tracking to repeat-pass satellite images including Landsat-5 (Band 4), Landsat-7 (Band 8), ERS1 SAR, ERS-2 Synthetic-aperture radar (SAR) and Envisat Advanced SAR (ASAR). Optical pairs were separated by 16 or 32 days, SAR pairs by 35 days, and errors are estimated to be less than $0.2 \mathrm{~m} \mathrm{day}^{-1}$ (Bevan et al., 2012). 


\subsection{Ocean and air temperature}

Figure 2 shows annual mean sub-surface water temperature (SSWT) anomalies obtained from the Met Office Hadley Centre EN3 model output (http://www.metoffice.gov. uk/hadobs/en3/). We use objective analyses performed by the Met Office Hadley Centre based on optimal interpolation of the in situ data profiles combined with a quality control system (Ingleby and Huddleston, 2007). We subtracted the 1981-2012 mean temperature to obtain the anomalies. The SSWT data has resolution of $1 \times 1^{\circ}$. The nearest grid points to Helheim and Kangerdlugssuaq glaciers are located immediately outside the fjord systems, where water depth is limited to a few hundred metres. Consequently, we use data in the EN3 model at $315 \mathrm{~m}$ depth. It should be noted that data coverage is highly non-uniform and includes large gaps, particularly between 1950 and 1965 (Ingleby and Huddleston, 2007).

Air temperature records for the two stations used in this study are obtained from The Danish Meteorological Institute (DMI) (Boas and Wang, 2011). The northern record close to Kangerdlugssuaq Glacier $(\sim 80 \mathrm{~km})$ is comprised of data from two coastal stations: 04350 (Apuiteeq; $13 \mathrm{~m}$ above sea level, a.s.1.), which operated until 1987, and 04351 which replaced it at the same location. Data gaps in the temperature record (1986, 2003, 2004, 2006, and 2007) are explained by the remoteness of the meteorological station which hindered instrument replacement. The temperature record close to Helheim Glacier $(\sim 85 \mathrm{~km})$ is from station 04360 (Tasiilaq; 50 m a.s.1.). We use the mean temperature from 1981 to 2012 as a reference period for temperature anomalies.

\subsection{Surface Mass Balance}

To isolate dynamically induced elevation changes, we use the Box (2013), hereafter BOX, reconstruction to estimate elevation changes due to surface mass balance (SMB) fluctuations. To obtain anomalies we remove the 1961-1990 mean annual SMB. We use bilinear interpolation to estimate SMB at each selected observed point. SMB, equal to net snow accumulation minus snow and ice meltwater runoff, was reconstructed on a $5 \mathrm{~km}$ grid for Greenland ice from 1840 to 2010 (Box, 2013). Reconstructed SMB is validated using data from the K-transect (van de Wal et al., 2012) along the western ice sheet and has an RMSE of roughly $0.45 \mathrm{~m}$ water equivalence. Compared to a typical regional climate model output (see, e.g., Vernon et al., 2012), the $5 \mathrm{~km}$ resolution facilitates the resolution of sharp spatial gradients in the ablation area and where terrain induces complex spatial structure in accumulation rates. Along the ice margin, the uncertainty is larger than $0.45 \mathrm{~m}$ for several reasons. The melt (and often accumulation) mass fluxes are largest in this region, a $5 \mathrm{~km}$ grid does not resolve glacier tongues well, and grid cells include some mixture of land, ice, and sea.
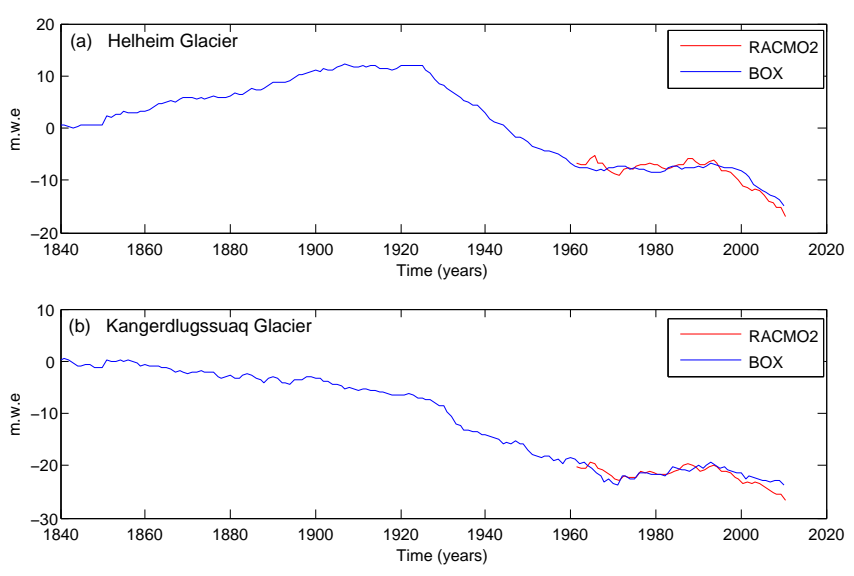

Figure 3. (a) Time series of cumulative melt-induced elevation changes in metre water equivalent ( $m$ w.e.) at the location marked by a white star in Fig. 4a; (b) same as (a) but for the location marked by a white star in Fig. 5a.

To evaluate and assess the BOX cumulative SMB, we use model results from the RACMO2-model (Ettema et al., 2009) (Fig. 3). RACMO2 is a high-resolution limitedarea model with physical processes adopted from the global model of the European Centre for Medium-Range Weather Forecasts (ECMWF). Its adaptation for the Greenland ice sheet, including the treatment of meltwater percolation and refreezing, as well as the evaluation of the modelled SMB, is described in Ettema et al. (2009 and 2010). The lateral boundary conditions are provided by ECMWF reanalyses, notably ERA-40 and ERA-Interim, and the model is run over the period of 1958 to 2011. Based on a comparison with observations, Ettema et al. (2009) concluded that the model performs very well in simulating accumulation $(N=265, r=0.95)$, yielding a $14 \%$ uncertainty in ice-sheet-integrated SMB. Figure 3 shows the time series of elevation changes at the points shown in Figs. 4a (Helheim Glacier) and 5a (Kangerdlugssuaq Glacier). The two models, BOX and RACMO2, agree very well.

\section{Method}

To estimate elevation change, we use ICESat and ATM track points that are less than $17 \mathrm{~m}$ from the nearest measured 1981 DEM point (i.e. within one DEM pixel) so that surface slope can be ignored. Combining our error estimates (rms), the thinning values for Helheim and Kangerdlugssuaq glaciers (shown in Figs. 4 and 5) have uncertainties of 5.1 and $9.4 \mathrm{~m}$, respectively (the uncertainties are derived using the same method as Khan et al. (2013), Kjær et al. (2012), and Motyka et al. (2010)). To estimate time series of surface elevation change at points represented as white stars in Fig. 4a (Helheim Glacier) and 5a (Kangerdlugssuaq Glacier), we use the $25 \times 25 \mathrm{~m}$ grid 1981 DEM , ICESat, and ATM 

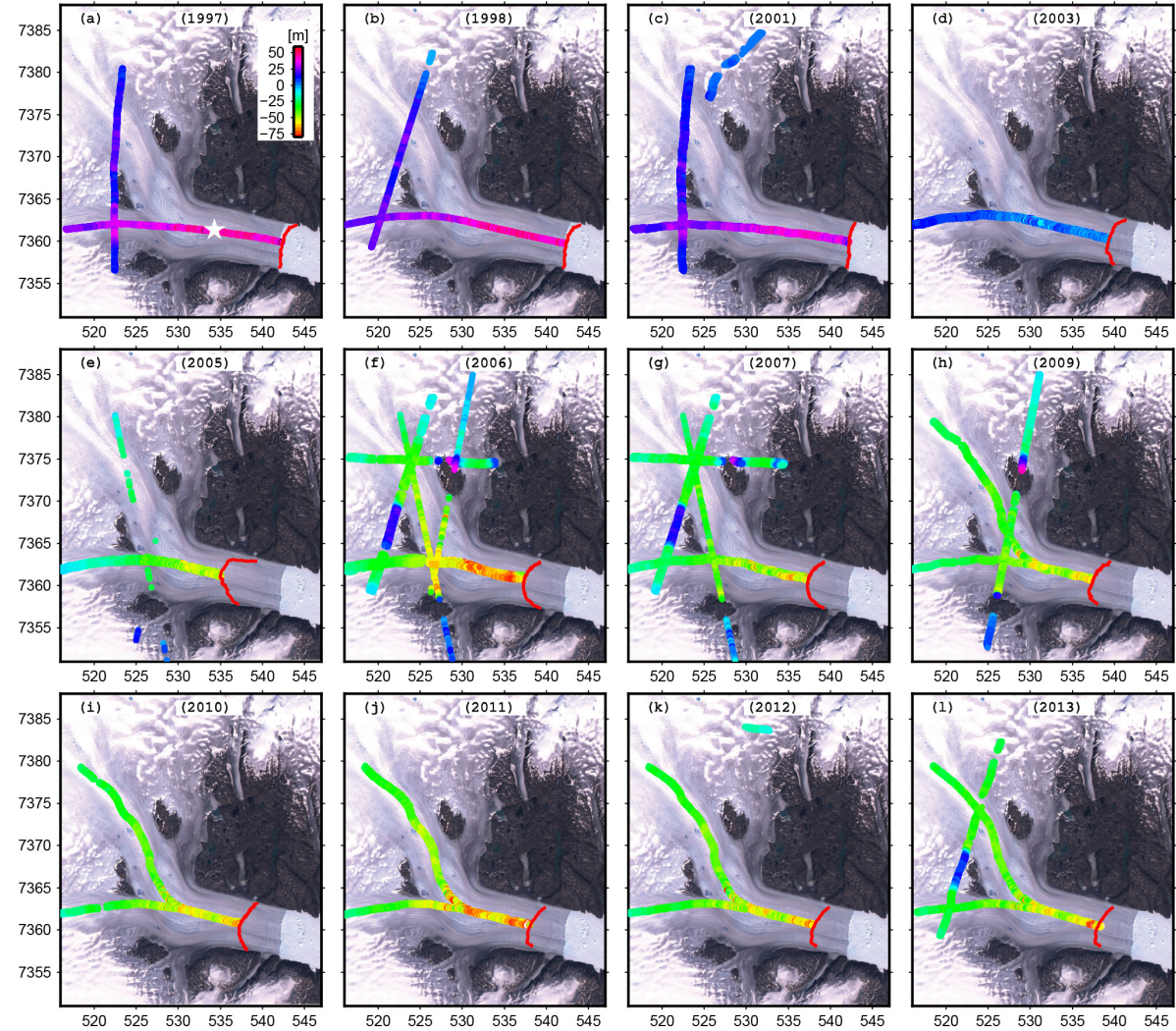

Figure 4. Elevation changes relative to 1981 on Helheim Glacier. Colours indicate the change in Helheim Glacier elevation relative to 1981 along the track lines. The colour bar is in metres. Uncertainties are $5.1 \mathrm{~m}$. Areas near the glacier margin show the greatest elevation change. The red line shows the position of the calving front. The panels show elevation changes of Helheim Glacier during (a) 1981-1997, (b) 1981-1998, (c) 1981-2001, (d) 1981-2003, (e) 1981-2005, (f) 1981-2006, (g) 1981-2007, (h) 1981-2009, (i) 1981-2010, (j) 19812011, (k) 1981-2012, (l) 1981-2013. The white star in (a) represents the location of the time series shown in Fig. 7a. The background map is a Landsat7 Enhanced Thematic Mapper (ETM)+ "true color" image from 2 August 2001. The axes displays UTM zone 24 coordinates in kilometres.

data. However, the flight lines in Figs. 4 and 5 do not perfectly overlap; thus, topography is corrected for using the $25 \times 25 \mathrm{~m}$ grid $1981 \mathrm{DEM}$. The maximum distance between the sample points shown in Figs. $4 \mathrm{a}$ and $5 \mathrm{a}$ and the observed points is $200 \mathrm{~m}$.

To extend the observational record to the century timescale, we use the so-called "historical moraines" (fresh non-vegetated moraines close to the present glacier ice front seen in many parts of Greenland) and fresh trimlines (pronounced boundaries between abraded and less abraded bedrock on valley sides) (Csatho et al., 2008). These mark the culmination of Little Ice Age (LIA) glacier advances and were formed at the end of the LIA. The precise timing of the retreat from the neoglacial maximum position is unknown. However, based on photographic evidence from the early 1930s, we can conclude that retreat from Little Ice Age maximum $\left(\right.$ LIA $_{\max }$ ) extent had started. The trimlines must therefore be LIA trimlines as no advances have been observed between LIA $_{\max }$ and 1930. The vertical aerial stereo photographs from 1981 were processed using the SOCET SET software package. This allows a 3D-mapping of features outlining the Little Ice Age maximum (LIA max $_{\text {) }}$ extent. Each of the true (Fig. 1b) sample locations contains two data points placed perpendicular to the flow direction, one being the elevation of the LIA max $_{\text {ax }}$ extent and the other being the elevation of the 1981 ice surface (see Fig. 6). The vertical difference $\left(\mathrm{d} h_{\text {LIA }}\right)$ is determined from these two data points. We assume that the cross-section profile of the glacier did not change significantly between the LIA $\mathrm{max}_{\max }$ and 1981. Because the elevations related to the $\mathrm{LIA}_{\max }$ are mapped using the 1981 imagery, any post-deposition effect on the moraines can be ignored. This also applies to corrections for glacial isostatic adjustment applied to both sample points which would cancel out.

The uncertainty of the measured height derived from stereo photogrammetry is given by

$\sigma_{Z}=m \cdot \sigma_{x^{\prime}} \cdot \frac{1}{h / b}$, 

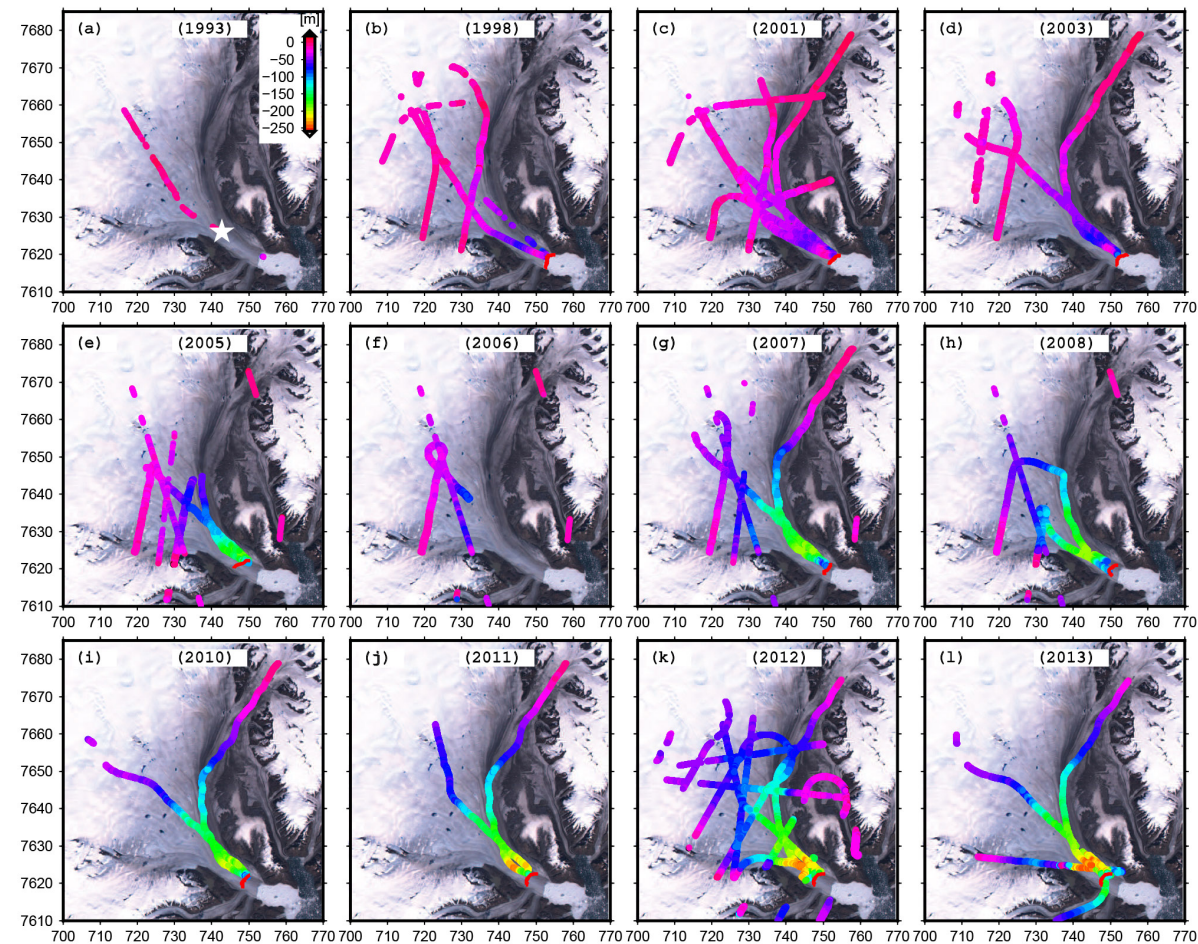

Figure 5. Elevation changes relative to 1981 on Kangerdlugssuaq Glacier. Same as for Fig. 4, but for Kangerdlugssuaq Glacier. The panels show elevation changes of Kangerdlugssuaq Glacier during (a) 1981-1993, (b) 1981-1998, (c) 1981-2001, (d) 1981-2003, (e) 1981-2005, (f) 1981-2006, (g) 1981-2007, (h) 1981-2008, (i) 1981-2010, (j) 1981-2011, (k) 1981-2012, (l) 1981-2013. The white star in (a) represents the location of the time series shown in Fig. 7b. The background map is a Landsat7 ETM+ "true color" image from 6 August 1999. The axes displays UTM zone 24 coordinates in kilometres.

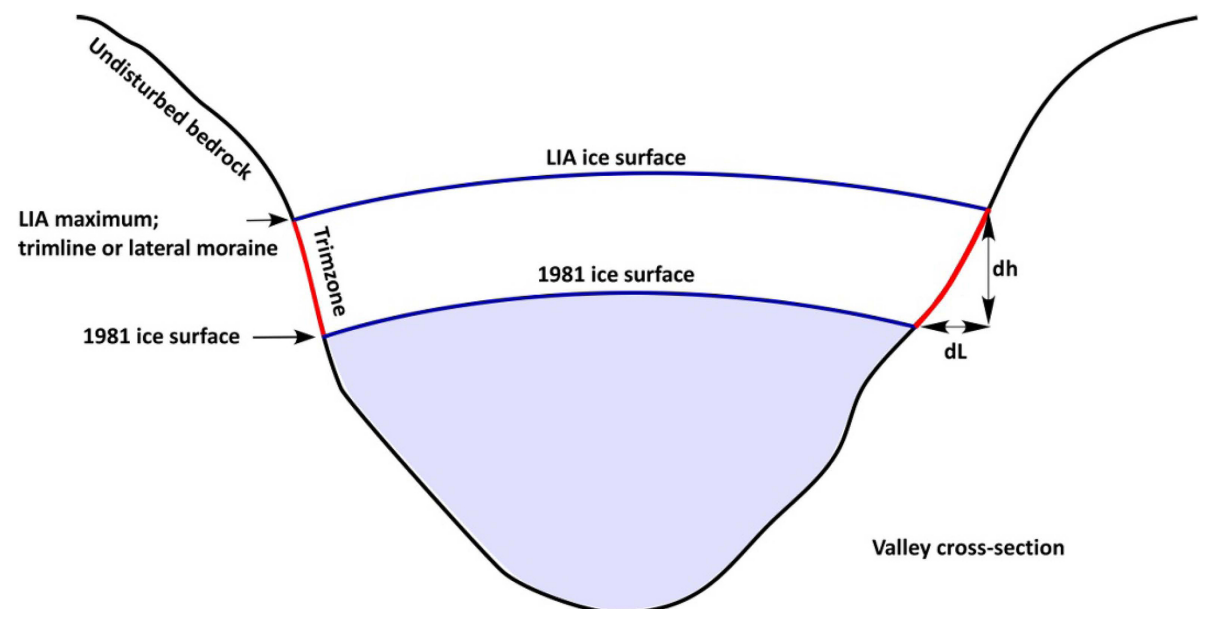

Figure 6. Sketch of outlet glacier perpendicular to the flow direction. Points are placed at the trimline or lateral moraine marking the LIA max position and the 1981 ice surface. The vertical difference $(\mathrm{d} h)$ is the thinning at each sample location.

where $m$ is the scale (nominally 150000), $h$ is the flying height $(\sim 13500 \mathrm{~m}), b$ is the baseline $(13600 \mathrm{~m})$, and $\sigma_{x^{\prime}}$ is the measurement uncertainty in the image coordinate system. This final value is take from the accuracy with which a manual stereo-measurement can be made, which is a third of a pixel $(5 \mu \mathrm{m})$.
We assume that proximity of the two measurements eliminate almost all systematic error from the triangulation of the imagery; the uncertainty on $\mathrm{d} h$ is then determined by the difference of two stereoscopically measured heights measured 

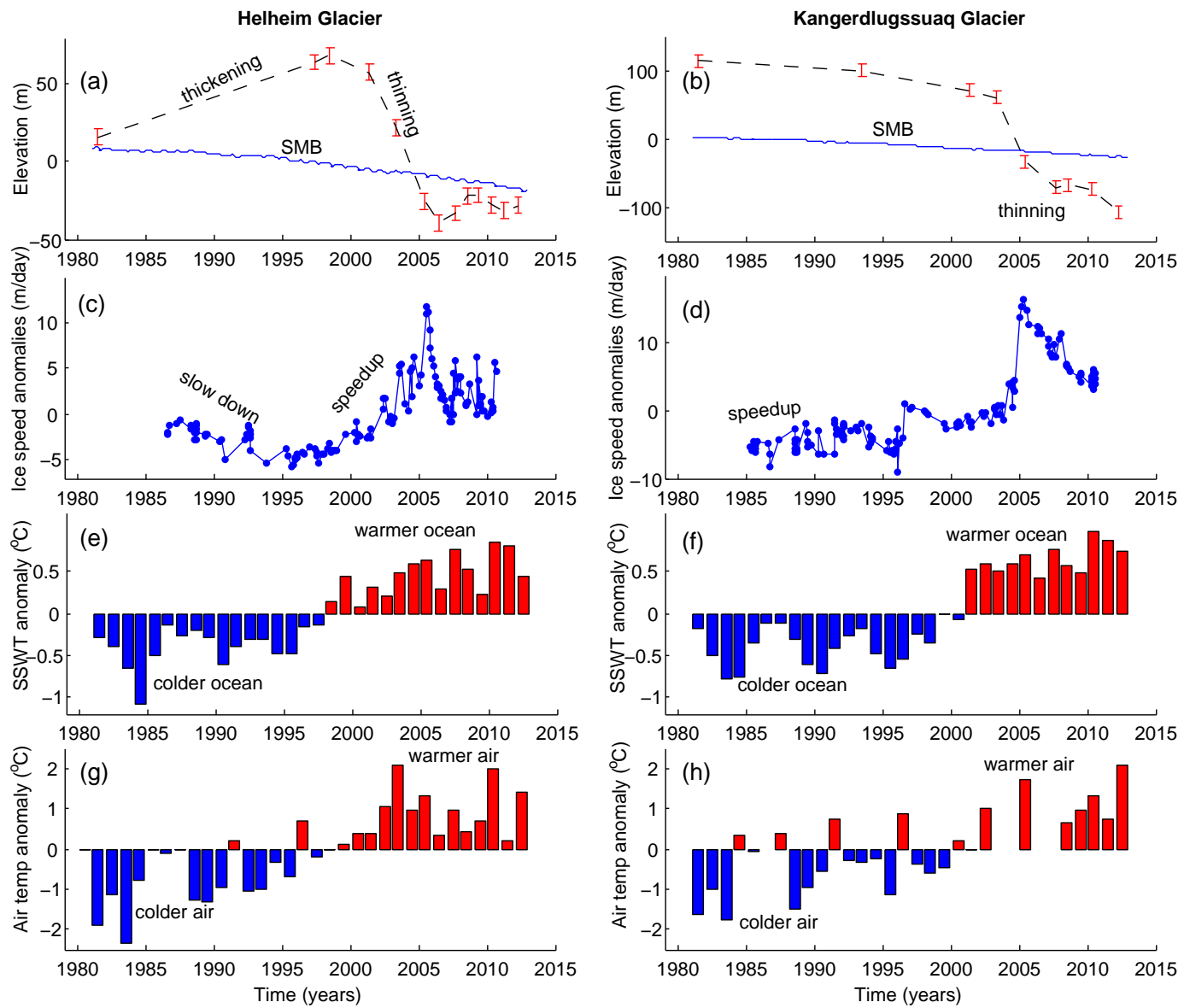

Figure 7. Time series of surface elevation change, surface velocity, sub-surface water temperature (SSWT), and air temperature. (a): Time series of elevation change relative to 1981 of Helheim Glacier at the location marked by the white star in Fig. 4a. (b): Same as for (a), but for Kangerdlugssuaq Glacier. Error bars of $\pm 5.1 \mathrm{~m}$ (Helheim Glacier) and $\pm 9.4 \mathrm{~m}$ (Kangerdlugssuaq Glacier) are displayed in (a) and (b), representing the combined vertical uncertainty in elevations. (c) and (d): Surface flow speed anomalies obtained from Bevan et al. (2012) for Helheim and Kangerdlugssuaq glaciers, respectively, in $\mathrm{m} \mathrm{yr}^{-1}$, with the mean flow speed from 1995 to 2012 removed. SSWT anomaly in degrees Celsius at point 1 (e) and point 2 (f) (see Fig. 1a for locations) with the mean temperature during 1981-2012 removed. Air temperature anomaly in degrees Celsius at Tasiilaq (g) and at Aputiteeq (h) with the mean temperature during 1981-2012 removed.

close to each other:

$\sigma_{\mathrm{d} h}=\sqrt{\sigma_{Z}^{2}+\sigma_{Z}^{2}}$,

This yields values $\sigma_{Z}=0.74 \mathrm{~m}$ and $\sigma_{\mathrm{d} h}=1.05 \mathrm{~m}$. Thus, we assign an uncertainty to $\sigma_{\mathrm{d} h}$ of $1 \mathrm{~m}$.

We note that elevation changes between the LIA $\mathrm{Aax}_{\max }$ and 1981 are derived from the margin of the ice flow whereas elevation changes after 1981 are derived from the centerline of the ice flow.

\section{Results and discussion}

\subsection{Thinning during 1981-2012}

In contrast to Helheim Glacier, Kangerdlugssuaq Glacier shows minor elevation changes from 1981 to 1993 (Figs. 5a and 7b). Thinning increased between 1993 and 1998, by which time the glacier had thinned by $50 \mathrm{~m}$, and continued by an additional $15-20 \mathrm{~m}$ until 2001 (Fig. 5a-c). Only small changes of 5-10 m were observed between 2001 and 2003 . Major thinning of more than $100 \mathrm{~m}$ occurred from 2003 to 2007, followed by more moderate fluctuations (Fig. 7b). In general, periods of slowdown and speed-up (Fig. 7c and d) agree very well with the estimates of dynamic thickening/thinning on both glaciers (Fig. 7a and b).

\subsection{Ocean and air temperature forcing}

Previous studies (e.g. Howat et al., 2008; Christoffersen et al., 2011) suggest that retreat and acceleration of HG (Helheim Glacier) and KG (Kangerdlugssuaq Glacier) in 2003 2004 is coupled to recent atmosphere and ocean warming. To investigate possible long-term forcing mechanisms capable 


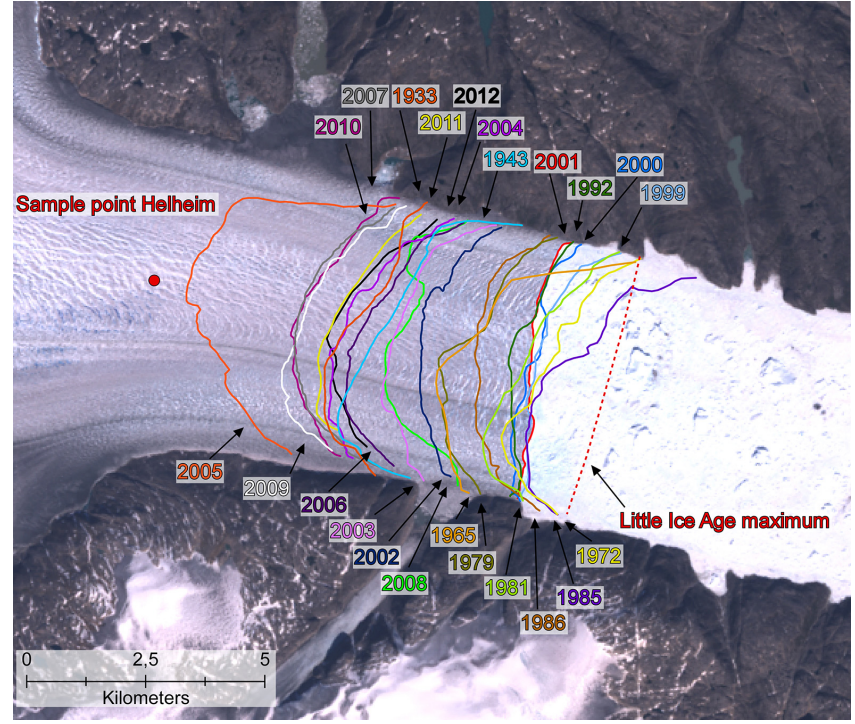

Figure 8. Frontal position of Helheim Glacier adopted from Bjørk et al. (2012). Oblique aerial image (1933), Vertical aerial image (1943), Corona satellite (1965), Landsat 1 Multi-Spectral Scanner (MSS) (1972 and 1979), Vertical aerial image (1981), Landsat 5 Thematic Mapper (TM) $(1985,1986,1992)$, Landsat 7 ETM+ (1999-2012). The red circle represents the location of the time series shown in Fig. 7a.

of triggering elevation changes, we analyse sub-surface water temperature, and near-surface air temperature variations. Figure 7e and $f$ show annual mean SSWT anomalies at point $1\left(65.5^{\circ} \mathrm{N}, 36.5^{\circ} \mathrm{W}\right)$ and $2\left(67.5^{\circ} \mathrm{N}, 31.5^{\circ} \mathrm{W}\right)$ (see Fig. 1). Ocean and atmospheric temperatures are relatively low until the late 1990s, after which they are consistently higher. The relatively colder water and air during 1981-1998 occurred when the frontal portion of Helheim Glacier thickened by $\sim 60 \mathrm{~m}$. The start of the somewhat warmer climate in 1998 seems to have halted the thickening of the glacier and instead started a rapid reversal of the process. Our results suggest that Helheim Glacier is very sensitive to even small fluctuations in the SSWT and air temperature. The simultaneous increase of SSWT and air temperature likely enhanced thinning of Helheim Glacier. A possible explanation is that rates of submarine melting increase in the presence of subglacial meltwater plumes in front of calving termini (Motyka et al., 2003; Rignot et al., 2010). The plumes promote melt because they introduce turbulent transfers at the ice-ocean boundary (Jenkins et al., 2010; Seale et al., 2011), enabling rapid retreat of the terminus. The retreat reduces downstream resistive stresses, which are redistributed upstream. Even though Kangerdlugssuaq Glacier experienced roughly the same climate forcing as Helheim Glacier (see Fig. 7e-h), no thickening occurred during the relatively cold period from 1981 to 1998. However, higher ocean and air temperatures from 1998 onward may have caused enhanced and rapid dynamic thinning.

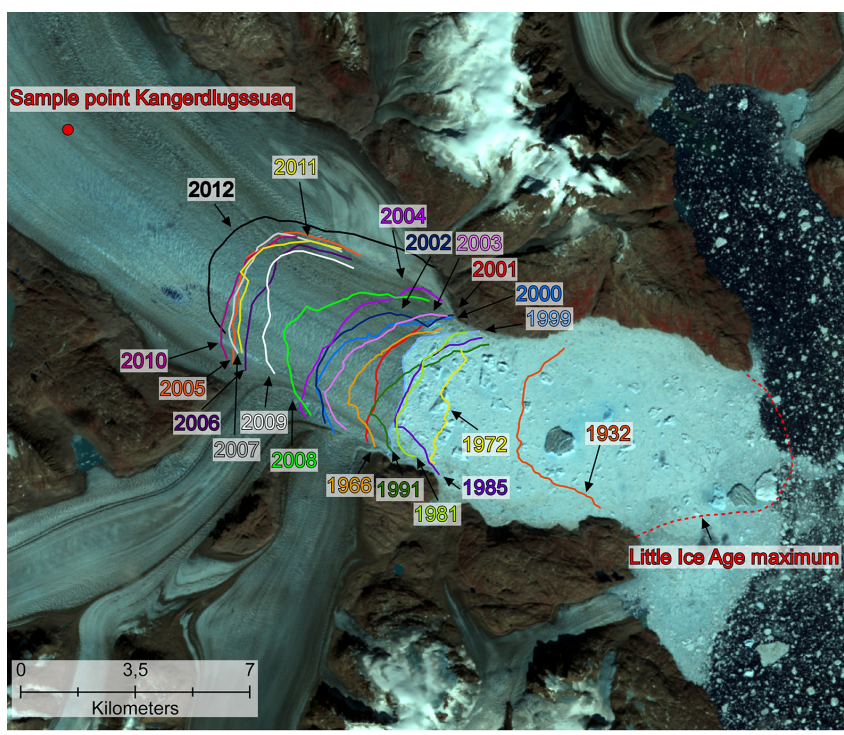

Figure 9. Frontal position of Kangerdlugssuaq Glacier obtained from Oblique aerial image (1932) and adopted from Bjørk et al. (2012), Corona satellite (1966), Vertical aerial image (1972 and 1981), Landsat 5 TM (1985 and 1991), and Landsat 7 ETM+ (1999_ 2012). The red circle represents the location of the time series shown in Fig. $7 b$.

\subsection{Thinning since the Little Ice Age}

At both Helheim and Kangerdlugssuaq glaciers, surface elevation and surface flow speed appear to be forced by atmospheric and oceanic changes. On short timescales both glaciers respond very quickly to atmospheric and oceanic fluctuations. To extend the observational record to the century timescale we use the historical moraines and fresh trimlines. Historical aerial imagery observations show that Helheim Glacier retreated from its LIA $_{\max }$ extent prior to 1933 (Fig. 8) while Kangerdlugssuaq Glacier retreated from its LIA $_{\max }$ extent between 1930 and 1932 (Fig. 9). Our results suggest Helheim Glacier experienced no elevation change between the LIA max $_{\text {and }} 1981$ (Fig. 1c), while Kangerdlugssuaq Glacier thinned by $230-265 \mathrm{~m}$ during the same period (Fig. 1b). The frontal position of Helheim Glacier retreated from the $\mathrm{LIA}_{\max }$ to 1933 , and, after that, advanced/retreated several times until 1981 (Bjørk et al., 2012) (see Fig. 8). Hence, Helheim Glacier likely experienced several periods of dynamic thinning and thickening; however, the overall elevation change during the LIA $_{\max }-1981$ is zero. In contrast, in the early 1930 s the marginal position of Kangerdlugssuaq Glacier was very close to the LIA maximum position, and during the course of a single year from 1932 to 1933 the advanced floating tongue collapsed and the front retreated more than $7 \mathrm{~km}$ (Wager et al., 1937; Spender, 1933), marking the onset of the Kangerdlugssuaq Glacier's 20th-century thinning. From the LIA maximum to 2012, the 

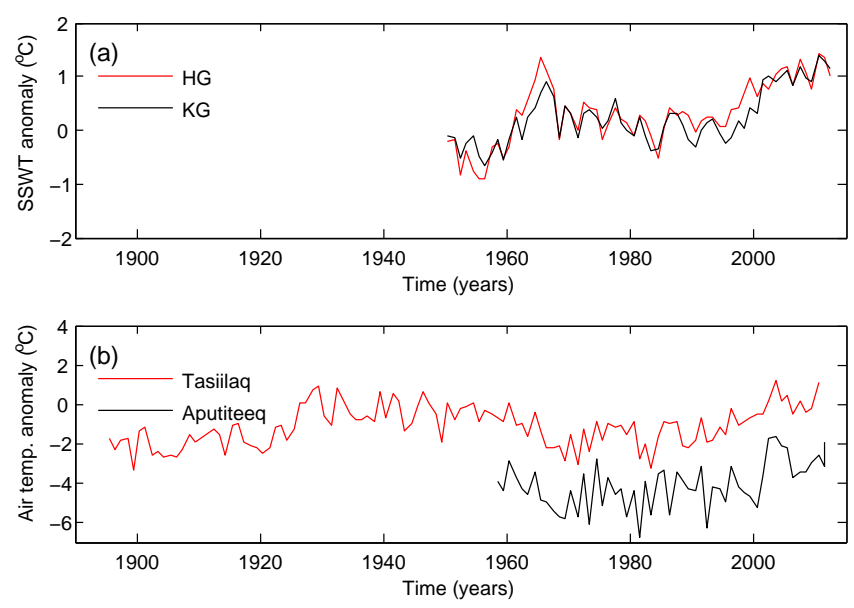

Figure 10. Time series of sub-surface water temperature, and air temperature. (a) SSWT anomaly in degrees Celsius at $315 \mathrm{~m}$ depth at point 1 (near Helheim Glacier - HG) and point 2 (near Kangerdlugssuaq Glacier - KG) (see Fig. 1a for locations), with the mean temperature during 1981-2012 removed, (b) Air temperature anomaly in degrees Celsius at Tasiilaq and at Aputiteeq.

frontal portion of Kangerdlugssuaq Glacier experienced major retreat and thinning by more than $500 \mathrm{~m}$ (Figs. $1 \mathrm{~b}$ and 9).

Though Helheim and Kangerdlugssuaq glaciers appear to respond similarly to short-term oceanic and atmospheric forcing (and they seem to experience similar long-term forcing - see Fig. 10), they exhibit quite different long-term behaviour, suggesting other forcing parameters may dominate the mass budget on century timescales. Sensitivity tests to outlet shape suggest small variations in bed topography can result in either stable or unstable retreat/advance due to the same perturbation (Enderlin et al., 2013). Figure 11c shows bed and ice surface profiles along the dashed line displayed in Fig. 11a. Helheim Glacier retreated until 2005 (see Fig. 8), when it reached a position where the glacier width rapidly increases farther inland and bed elevation starts to rise. Kangerdlugssuaq Glacier has a different geometry. The channel where the glacier width is relatively small $(5-7 \mathrm{~km})$ is about $27 \mathrm{~km}$ long, and the glacier has yet not reached the position where the channel width rapidly increases (see Fig. 11d). Furthermore, bed elevation keeps decreasing upstream from the glacier (though there are some bumps). Taking the geometry into account, Kangerdlugssuaq Glacier could potentially retreat an additional 8-10 km from its 2012 position until it reaches the end of the narrow channel. However, the retreat may be affected by the bedrock bumps, which could have a stabilising effect (Jamieson et al., 2012).

\section{Conclusions}

Our results suggest Helheim Glacier experienced no net elevation change during the $\mathrm{LIA}_{\max }-1981$, while Kangerdlugssuaq Glacier underwent substantial thinning of 230
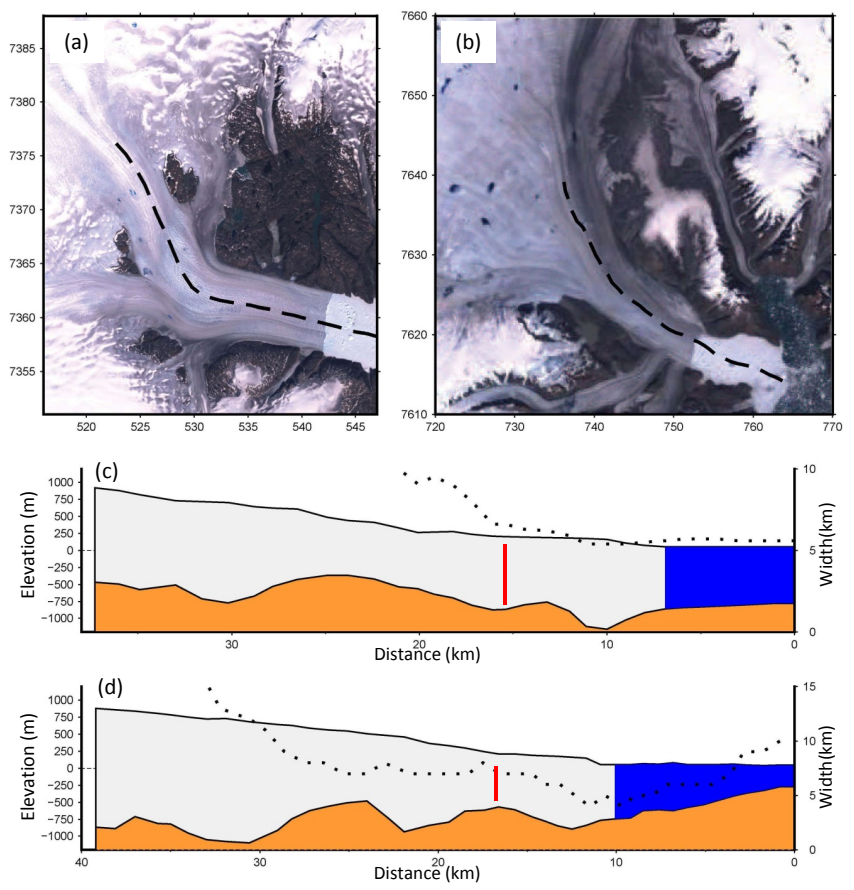

Figure 11. (a): Landsat7 ETM+ "true color" image of Helheim Glacier from 2 August 2001; (b): Landsat7 ETM+ "true color" image of Kangerdlugssuaq Glacier from 6 August 1999; (c): Bedrock and ice surface profiles along the dashed line shown in (a). The dotted curve represents width of Helheim Glacier along the same profile. The vertical red line denotes minimum retreat of the Helheim Glacier (which occurred in 2005, see Fig. 8). (d): Same as (c) but for Kangerdlugssuaq Glacier. The minimum retreat of the Kangerdlugssuaq Glacier occurred in 2012 (see Fig. 9). Bed data is obtained from Bamber et al. (2013).

$265 \mathrm{~m}$. Kangerdlugssuaq Glacier has a bed which deepens inland and the glacier front has retreated throughout the last century (see Fig. 8). The frontal portion of Kangerdlugssuaq Glacier flows through a 5-7 km wide and more than $27 \mathrm{~km}$ long channel. The current position of the front is approximately in the middle of the narrow channel. Potentially, Kangerdlugssuaq Glacier could continue retreating. Helheim Glacier has retreated and advanced several times throughout the last century; however, likely due to rapid increase of the glacier width and bed elevation farther inland, the retreats have been followed by advances (e.g. during 2005-2006), suggesting both bed and width (see Fig. 11c) play an important role in the Helheim Glacier stability and long-term mass balance.

Although atmospheric and oceanic forcing is able to capture changes on multiyear timescales very well (Nick et al., 2013; Price et al., 2011), on century timescales, multiple external parameters (e.g. bed elevation, width and/or grounding line migration, Jamieson et al., 2012) likely dominate the mass change. These findings suggest that long-term data records - as initial conditions that capture the mass balance 
between episodic events - are preferred to extrapolate mass balance estimates into the future.

Acknowledgements. We thank Andreas Vieli, Ellyn M. Enderlin, and an anonymous reviewer for their comments. Shfaqat Abbas Khan was partly supported by KVUG and the Danish Council for Independent Research - Nature and Universe. Andy Aschwanden was supported by NASA grant NNX13AK27G.

Edited by: A. Vieli

\section{References}

Bamber, J. L., Griggs, J. A., Hurkmans, R. T. W. L., Dowdeswell, J. A., Gogineni, S. P., Howat, I., Mouginot, J., Paden, J., Palmer, S., Rignot, E., and Steinhage, D.: A new bed elevation dataset for Greenland, The Cryosphere, 7, 499-510, doi:10.5194/tc-7499-2013, 2013.

Bevan, S. L., Luckman, A. J., and Murray, T.: Glacier dynamics over the last quarter of a century at Helheim, Kangerdlugssuaq and 14 other major Greenland outlet glaciers, The Cryosphere, 6, 923-937, doi:10.5194/tc-6-923-2012, 2012.

Bjørk, A. A., Kjær, K. H., Korsgaard, N. J., Khan, S. A., Kjeldsen, K. K., Andresen, C. S., Box, J. E., Larsen, N. K., and Funder, S.: An aerial view of 80 years of climate-related glacier fluctuations in southeast Greenland, Nat. Geosci., 5, 427-432, doi:10.1038/ngeo1481, 2012.

Boas, L. and Wang, P. R.: Weather and climate data from Greenland 1958-2010, Danish Meteorological Institute, DMI Technical Report 11-15, 2011.

Box, J. E.: Greenland ice sheet mass balance reconstruction. Part II: Surface mass balance (1840-2010), J. Climate, 26, 6974-6989, 2013.

Csatho, B., Schenk, T., Van Der Veen, C. J., and Krabill, W. B.: Intermittent thinning of Jakobshavn Isbræ, West Greenland, since the Little Ice Age, J. Glaciol., 54, 131-144, 2008.

Chen, J. L., Wilson, C. R., and Tapley, B. D.: Interannual variability of Greenland ice losses from satellite gravimetry, J. Geophys. Res., 116, B07406, doi:10.1029/2010JB007789, 2011.

Christoffersen, P., Mugford, R. I., Heywood, K. J., Joughin, I., Dowdeswell, J. A., Syvitski, J. P. M., Luckman, A., and Benham, T. J.: Warming of waters in an East Greenland fjord prior to glacier retreat: mechanisms and connection to large-scale atmospheric conditions, The Cryosphere, 5, 701-714, doi:10.5194/tc5-701-2011, 2011.

Enderlin, E. M., Howat, I. M., and Vieli, A.: High sensitivity of tidewater outlet glacier dynamics to shape, The Cryosphere, 7, 1007-1015, doi:10.5194/tc-7-1007-2013, 2013.

Ettema, J., van den Broeke, M. R., van Meijgaard, E., van de Berg, W. J., Bamber, J. L., Box, J. E., and Bales, R. C.: Higher surface mass balance of the Greenland ice sheet revealed by highresolution climate modeling, Geophys. Res. Lett., 36, L12501, doi:10.1029/2009GL038110, 2009.

Ettema, J., van den Broeke, M. R., van Meijgaard, E., van de Berg, W. J., Box, J. E., and Steffen, K.: Climate of the Greenland ice sheet using a high-resolution climate model - Part 1: Evaluation, The Cryosphere, 4, 511-527, doi:10.5194/tc-4-511-2010, 2010.
Howat, I. M., Joughin, I., and Scambos, T. A.: Rapid changes in ice discharge from Greenland outlet glaciers, Science, 315, 15591561, 2007.

Howat, I. M., Joughin, I., Fahnestock, M., Smith, B. E., and Scambos, T.: Synchronous retreat and acceleration of southeast Greenland outlet glaciers 2000-2006: ice dynamics and coupling to climate, J. Glaciol., 54, 646-660, 2008.

Ingleby, B. and Huddleston, M.: Quality control of ocean temperature and salinity profiles - historical and real-time data, J. Marine Syst., 65, 158-175, doi:10.1016/j.jmarsys.2005.11.019, 2007.

Jamieson, S. S. R., Vieli, A., Livingstone, S. J., Cofaigh, C., Stokes, C., Hillenbrand, C.-D., and Dowdeswell, J. A.: Ice-stream stability on a reverse bed slope, Nat. Geosci., 5, 799-802, 2012.

Jenkins, A., Nicholls, K. W., and Corr, H. F. J.: Observation and parameterization of ablation at the base of Ronne Ice Shelf, Antarctica, J. Phys. Oceanogr., 40, 2298-2311, 2010.

Joughin, I., Smith, B. E., Howat, I. M., Scambos, T., and Moon, T.: Greenland flow variability from ice-sheet-wide velocity mapping, J. Glaciol., 56, 415-430, 2010.

Khan, S. A., Wahr, J., Stearns, L. A., Hamilton, G. S., van Dam, T., Larson, K. M., and Francis, O.: Elastic uplift in southeast Greenland due to rapid ice mass loss, Geophys. Res. Lett., 34, L21701, doi:10.1029/2007GL031468, 2007.

Khan, S. A., Wahr, J., Bevis, M., Velicogna, I., and Kendrick, E.: Spread of ice mass loss into northwest Greenland observed by GRACE and GPS, Geophys. Res. Lett., 37, L06501, doi:10.1029/2010GL042460, 2010.

Khan, S. A., Kjær, K. H., Korsgaard, N. J., Wahr, J., Joughin, I. R., Timm, L. H., Bamber, J. L., van den Broeke, M. R., Stearns, L. A., Hamilton, G. S., Csatho, B. M., Nielsen, K., Hurkmans, R., and Babonis, G.: Recurring dynamically induced thinning during 1985 to 2010 on Upernavik Isstrøm, West Greenland, J. Geophys. Res.-Earth, 118, 111-121, doi:10.1029/2012JF002481, 2013.

Khan, S. A., Kjaer, K. H., Bevis, M., Bamber, J. L., Wahr, J., Kjeldsen, K. K., Bjork, A. A., Korsgaard, N. J., Stearns, L. A., van den Broeke, M. R., Liu, L., Larsen, N. K., and Muresan, I. S.: Sustained mass loss of the northeast Greenland ice sheet triggered by regional warming, Nature Clim. Change, 4, 292-299, doi:10.1038/NCLIMATE2161, 2014.

Kjær, K. H., Khan, S. A., Korsgaard, N. J., Wahr, J., Bamber, J. L., Hurkmans, R., van den Broeke, M., Timm, L. H., Kjeldsen, K. K., Bjørk, A. A., Larsen, N. K., Jørgensen, L. T., FærchJensen, A., and Willerslev, E.: Aerial Photographs Reveal Late20th-Century Dynamic Ice Loss in Northwestern Greenland, Science, 337, doi:10.1126/science.1220614, 2012.

Krabill, W. B.: IceBridge ATM L2 Icessn Elevation, Slope, and Roughness, [1993-2012]. Boulder, Colorado USA: NASA Distributed Active Archive Center at the National Snow and Ice Data Center, Digital media, http://nsidc.org/data/ilatm2.html, 2012.

Luckman, A., Murray, T., de Lange, R., and Hanna, E.: Rapid and synchronous ice-dynamic changes in east Greenland, Geophys. Res. Lett., 33, L03503, doi:10.1029/2005GL025428, 2006.

Luthcke, S. B., Zwally, H. J., Abdalati, W., Rowlands, D. D., Ray, R. D., Nerem, R. S., Lemoine, F. G., McCarthy, J. J., and Chinn, D. S.: Recent Greenland ice mass loss by drainage system from satellite gravity observations, Science, 314, 1286-1289, 2006.

Motyka, R. J., Hunter, L., Echelmeyer, K. A., and Connor, C.: Submarine melting at the terminus of a temperate tidewater 
glacier, LeConte Glacier, Alaska, U.S.A, Ann. Glaciol., 36, 5765, doi:10.3189/172756403781816374, 2003.

Motyka, R. J., Fahnestock, M., and Truffer, M.: Volume change of Jakobshavn Isbræ, West Greenland: 1985-1997-2007, J. Glaciol., 56, 635-646, doi:10.3189/002214310793146304, 2010.

Nick, F. M., Vieli, A., Andersen, M. L., Joughin, I., Payne, A., Edwards, T. L., Pattyn, F., and van deWal, R. S. W.: Future sea-level rise from Greenland's main outlet glaciers in a warming climate, Nature, 497, 235-238, doi:10.1038/nature12068, 2013.

Price, S. F., Payne, A. J., Howat, I. M., and Smith, B. E.: Committed sea-level rise for the next century from Greenland ice sheet dynamics during the past decade, P. Natl. Acad. Sci. USA, 108, 8978-8983, doi:10.1073/pnas.1017313108, 2011.

Pritchard, H. D., Arthern, R. J., Vaughan, D. G., and Edwards, L. A.: Extensive dynamic thinning on the margins of the Greenland and Antarctic ice sheets, Nature, 461, 971-975, 2009.

Rignot, E., Box, J. E., Burgess, E., and Hanna, E.: Mass balance of the Greenland ice sheet from 1958 to 2007, Geophys. Res. Lett., 35, L20502, doi:10.1029/2008GL035417, 2008.

Rignot, E., Koppes, M., and Velicogna, I.: Rapid submarine melting of the calving faces of West Greenland glaciers, Nat. Geosci., 3, 187-191, doi:10.1038/ngeo765, 2010.

Seale, A., Christoffersen, P., Mugford, R. I., and O'Leary, M.: Ocean forcing of the Greenland Ice Sheet: Calving fronts and patterns of retreat identified by automatic satellite monitoring of eastern outlet glaciers, J. Geophys. Res., 116, F03013, doi:10.1029/2010JF001847, 2011.

Spender, M.: Mapmaking during the Expedition, Meddelelser om Grønland, Vol. 104, No. 2, 1933.
Stearns, L. A. and Hamilton, G. S.: Rapid volume loss from two East Greenland outlet glaciers quantified using repeat stereo satellite imagery, Geophys. Res. Lett., 34, L05503, doi:10.1029/2006GL028982, 2007.

van den Broeke, M., Bamber, J., Ettema, J., Rignot, E., Schrama, E., van de Berg, W. J., van Meijgaard, E., Velicogna, I., and Wouters, B.: Partitioning Recent Greenland Mass Loss, Science, 326, 984 986, 2009.

van de Wal, R. S. W., Boot, W., Smeets, C. J. P. P., Snellen, H., van den Broeke, M. R., and Oerlemans, J.: Twenty-one years of mass balance observations along the K-transect, West Greenland, Earth Syst. Sci. Data, 4, 31-35, doi:10.5194/essd-4-312012, 2012.

Velicogna, I. and Wahr, J.: Acceleration of Greenland ice mass loss in spring 2004, Nature, 443, 329-331, 2006.

Vernon, C. L., Bamber, J. L., Box, J. E., van den Broeke, M. R., Fettweis, X., Hanna, E., and Huybrechts, P.: Surface mass balance model intercomparison for the Greenland ice sheet, The Cryosphere, 7, 599-614, doi:10.5194/tc-7-599-2013, 2013.

Wager, L., Deer, W., Wager, H., and Manley, G.: The Kangerdlugssuak Region of East Greenland, Geogr. J., 90, 393-421, 1937.

Zwally, H. J., Schutz, R., Bentley, C., Bufton, J., Herring, T., Minster, J., Spinhirne, J., and Thomas, R.: GLAS/ICESat L2 Antarctic and Greenland Ice Sheet Altimetry Data V031, Boulder, Colorado: NASA Distributed Active Archive Center at the National Snow and Ice Data Center, Digital media, 2012. 